\title{
Synthesis and Characterization of $\mathrm{LiNi}_{1 / 3} \mathrm{Co}_{1 / 3} \mathrm{Mn}_{1 / 3} \mathrm{O}_{2-x} \mathrm{Cl}_{x}$ as Cathode Materials for Lithium Ion Batteries at $55^{\circ} \mathrm{C}$
}

\author{
Hai-Lang Zhang and Shuixiang Liu \\ School of Chemical and Material Engineering, Jiangnan University, Wuxi, Jiangsu 214122, China \\ Correspondence should be addressed to Hai-Lang Zhang; zhl8868@vip.163.com
}

Received 14 May 2013; Revised 27 September 2013; Accepted 2 October 2013

Academic Editor: Dachamir Hotza

Copyright (C) 2013 H.-L. Zhang and S. Liu. This is an open access article distributed under the Creative Commons Attribution License, which permits unrestricted use, distribution, and reproduction in any medium, provided the original work is properly cited.

\begin{abstract}
A series of materials based on the $\mathrm{LiNi}_{1 / 3} \mathrm{Co}_{1 / 3} \mathrm{Mn}_{1 / 3} \mathrm{O}_{2-x} \mathrm{Cl}_{x}$ system were prepared by a sol-gel method, and their phase formation processes, crystal structures, and electrochemical performances were studied by thermogravimetric analyses (TG/DTG), X-ray diffraction (XRD), charge-discharge tests, and cyclic voltammetry (CV). The XRD patterns indicate that the $\mathrm{LiNi}_{1 / 3} \mathrm{Co}_{1 / 3} \mathrm{Mn}_{1 / 3} \mathrm{O}_{2-x} \mathrm{Cl}_{x}$ powders with better crystalline structure could be obtained at calcining temperature $850^{\circ} \mathrm{C}$ for $20 \mathrm{~h}$ under air atmosphere and show that the chlorine addition may induce the change of lattice parameters. The charge-discharge tests show that both the specific capacities and capacity retentions of $\mathrm{Cl}$-doped materials increase compared to the undoped material, especially for the capacity retention at the high-voltage region. At $55^{\circ} \mathrm{C}$, the $\mathrm{LiNi}_{1 / 3} \mathrm{Co}_{1 / 3} \mathrm{Mn}_{1 / 3} \mathrm{O}_{2-0.10} \mathrm{Cl}_{0.10}$ cathode material shows the highest initial discharge capacity of $180.1 \mathrm{mAh} \cdot \mathrm{g}^{-1}$ and the best capacity retention with the value of $91.9 \%$ after $100 \mathrm{cycles}$ in the region of $2.0-4.4 \mathrm{~V}$ at $0.1 \mathrm{C}$, while the initial discharge capacity is $208.2 \mathrm{mAh} \cdot \mathrm{g}^{-1}$ when the charge cutoff voltage is up to $4.6 \mathrm{~V}$.
\end{abstract}

\section{Introduction}

Lithiumion batteries have been investigated extensively by people for their high working voltage, high energy density, and long cyclic life to be used in electronic devices and power tools. A significant challenge of lithiumion battery improvement is to find a proper cathode material as an attractive candidate of next-generation cathode materials to replace $\mathrm{LiCoO}_{2}$. Although $\mathrm{LiCoO}_{2}$ is the predominant cathode material, its high cost and toxicity limit its further development. Recently, several other positive electrode materials, such as $\mathrm{LiNiO}_{2}, \mathrm{LiMn}_{2} \mathrm{O}_{4}, \mathrm{LiNi}_{1 / 3} \mathrm{Co}_{1 / 3} \mathrm{Mn}_{1 / 3} \mathrm{O}_{2}$, and $\mathrm{LiFePO}_{4}$, have been researched [1-4]. However, $\mathrm{LiNiO}_{2}$ suffers from safety and stability problems; $\mathrm{LiMn}_{2} \mathrm{O}_{4}$ has serious capacity fading problem during cycling, especially at higher temperatures, and $\mathrm{LiFePO}_{4}$ suffers from lower conductivity [1-3]. Layer-structured $\mathrm{LiNi}_{1 / 3} \mathrm{Co}_{1 / 3} \mathrm{Mn}_{1 / 3} \mathrm{O}_{2}$ cathode material has attracted much attention for it integrates the features of $\mathrm{LiCoO}_{2}, \mathrm{LiNiO}_{2}$, and $\mathrm{LiMn}_{2} \mathrm{O}_{4}$ with higher structural stability, higher capacity, lower cost, higher safety, and so on. It has been found that the predominant oxidation states of $\mathrm{Ni}, \mathrm{Co}$, and $\mathrm{Mn}$ are $+2,+3$, and +4 , respectively. $\mathrm{Ni}^{2+}$ and $\mathrm{Co}^{3+}$ are electrochemically active for redox reaction; however, $\mathrm{Mn}^{4+}$ is electrochemically inactive to stabilize the crystal structure $[4,5] . \mathrm{LiNi}_{1 / 3} \mathrm{Co}_{1 / 3} \mathrm{Mn}_{1 / 3} \mathrm{O}_{2}$ has been studied extensively because it has fast capacity fading due to the electrolyte decomposition and the structural decay of the electrode itself [6-8]. Moreover, the degree of capacity fading increases with the increase of charge cutoff voltage, in which is mainly due to gradual decaying of electroactive Co [4]. In general, it is believed that the valence of transition-metal ions changes during $\mathrm{Li}^{+}$intercalation and deintercalation. Tsai et al. [9] reported that the whole $\mathrm{Ni}^{2+}$ ions are oxidized to Jahn-Teller active $\mathrm{Ni}^{3+}$ ions, which twostep redox reactions of $\mathrm{Ni}^{2+} / \mathrm{Ni}^{3+}$ and $\mathrm{Ni}^{3+} / \mathrm{Ni}^{4+}$ occur during cycling, and the initial irreversible capacity is mainly due to that a part of $\mathrm{Ni}^{3+}$ and $\mathrm{Ni}^{4+}$ cannot be reduced to $\mathrm{Ni}^{2+}$ and also proved that the function of oxygen is to be the electron donor at the end of charge. It may be an effective way that partial $\mathrm{O}^{2-}$ substitution by $\mathrm{F}^{-}$would enhance the electrochemical performance [10-12]. However, the fluorine addition could lower the conductivity as $\mathrm{F}^{-}$is harder to lose electrons than $\mathrm{O}^{2-}$. Li et al. [13] reported that chlorine 
TABLE 1: Lattice parameters of the $\mathrm{LiNi}_{1 / 3} \mathrm{Co}_{1 / 3} \mathrm{Mn}_{1 / 3} \mathrm{O}_{2-x} \mathrm{Cl}_{x}$ cathode material.

\begin{tabular}{lccccc}
\hline$X$ & $a(\AA)$ & $c(\AA)$ & $c / a$ & $V\left(\AA^{3}\right)$ & $I_{003} / I_{104}$ \\
\hline 0.00 & 2.858 & 14.228 & 4.978 & 100.61 & 1.32 \\
0.05 & 2.861 & 14.231 & 4.974 & 100.89 & 1.38 \\
0.10 & 2.861 & 14.249 & 4.980 & 101.01 & 1.37 \\
0.15 & 2.862 & 14.254 & 4.980 & 101.11 & 1.37 \\
\hline
\end{tabular}

addition may increase the specific capacity and enhance the cyclic stability of $\mathrm{LiNi}_{0.7} \mathrm{Co}_{0.3} \mathrm{O}_{2}$, which is conductive for their electrochemical performance due to that $\mathrm{Cl}^{-}$is easier to lose electrons than $\mathrm{O}^{2-}$. Sun et al. [14] also reported that Cl-doping has improved the high-rate capability of $\mathrm{LiFePO}_{4}$ owing to the improvement of the $\mathrm{Li}^{+}$ion diffusion.

The goal of this work is to synthesize the $\mathrm{Cl}$-doped $\mathrm{LiNi}_{1 / 3} \mathrm{Co}_{1 / 3} \mathrm{Mn}_{1 / 3} \mathrm{O}_{2}$ cathode materials and understand the effect of chlorine addition on the structure and electrochemical properties of $\mathrm{LiNi}_{1 / 3} \mathrm{Co}_{1 / 3} \mathrm{Mn}_{1 / 3} \mathrm{O}_{2}$, especially at higher temperature. Because more and reliable results could be obtained by measuring the high temperature chargedischarge performance. To our knowledge, this is the first time to report $\mathrm{Cl}$-doped $\mathrm{LiNi}_{1 / 3} \mathrm{Co}_{1 / 3} \mathrm{Mn}_{1 / 3} \mathrm{O}_{2}$ cathode materials.

\section{Experimental}

2.1. The Preparation of $\mathrm{LiNi}_{1 / 3} \mathrm{Co}_{1 / 3} \mathrm{Mn}_{1 / 3} \mathrm{O}_{2-x} \mathrm{Cl} x$ Powders. $\mathrm{LiNi}_{1 / 3} \mathrm{Co}_{1 / 3} \mathrm{Mn}_{1 / 3} \mathrm{O}_{2-x} \mathrm{Cl}_{x}(x=0.00,0.05,0.10,0.15)$ powders were prepared via a sol-gel route using citric acid as chelating agent. A stoichiometric amount of $\mathrm{LiCH}_{3} \mathrm{COO}$. $2 \mathrm{H}_{2} \mathrm{O}(\mathrm{AR}), \quad \mathrm{Ni}\left(\mathrm{CH}_{3} \mathrm{COO}\right)_{2} \cdot 4 \mathrm{H}_{2} \mathrm{O}(\mathrm{AR}), \mathrm{Mn}\left(\mathrm{CH}_{3} \mathrm{COO}\right)_{2}$. $4 \mathrm{H}_{2} \mathrm{O}(\mathrm{AR}), \mathrm{Co}\left(\mathrm{CH}_{3} \mathrm{COO}\right)_{2} \cdot 4 \mathrm{H}_{2} \mathrm{O}(\mathrm{AR})$ and $\mathrm{LiCl} \cdot \mathrm{H}_{2} \mathrm{O}(\mathrm{AR})$ was dissolved in deionized water, and then the aqueous solution of citric acid was added to the mixture of metal ion solution. The $\mathrm{pH}$ was adjusted to $7 \sim 8$ by ammonium hydroxide. The reagent solution was stirred continuously at $80^{\circ} \mathrm{C}$ until homogeneous sol-gel formed. The resulting gel was dried at $120^{\circ} \mathrm{C}$ for $8 \mathrm{~h}$ and then heated at $500^{\circ} \mathrm{C}$ for $6 \mathrm{~h}$ to eliminate the organic residues. The powders were thoroughly ground and then calciniated at $850^{\circ} \mathrm{C}$ for $20 \mathrm{~h}$ in air and followed by quenching to room temperature.

2.2. The Characterization of $\mathrm{LiNi}_{1 / 3} \mathrm{Co}_{1 / 3} \mathrm{Mn}_{1 / 3} \mathrm{O}_{2-x} \mathrm{Cl}_{x}$ Powders. TG/DTG was used to analyze the thermal process and phase formation process of the gel precursor from $50^{\circ} \mathrm{C}$ to $1000^{\circ} \mathrm{C}$ at a rate of $10^{\circ} \mathrm{C} / \mathrm{min}$ under a nitrogen atmosphere.

The X-ray diffraction (XRD) with $\mathrm{Cu} \mathrm{K} \alpha$ radiation operated at $40 \mathrm{kV}$ and $40 \mathrm{~mA}$ was used to analyze the crystalline structure of samples. The scan data were in the $2 \theta$ range from $10^{\circ}$ to $90^{\circ}$ in a step of $4^{\circ} / \mathrm{min}$.

The electrochemical properties of samples were carried out using two-electrode coin cells (type CR2032) assembled in an argon filled glove box. The positive electrodes were prepared by blending $80 \%$ active material, $12 \%$ acetylene black, and $8 \%$ polyvinylidene fluoride in $\mathrm{N}$-methyl-2-pyrrolidone (NMP). Then the slurry was spread on an aluminum foil as current collector using the Doctor-blade technique and dried at $80^{\circ} \mathrm{C}$ for $10 \mathrm{~h}$ in a vacuum oven. Microporous polypropylene membrane (Celgard 2325) was used as the separator. The electrolyte is LB-315 which consists of a $1 \mathrm{M}$ LiPF6 solution in DMC: EMC: EC $(1: 1: 1, \mathrm{v} / \mathrm{v} / \mathrm{v})$. The chargedischarge was tested in the potential range of $2.0 \sim 4.4$ or $4.6 \mathrm{~V}$ at different rates at elevated temperature $\left(55^{\circ} \mathrm{C}\right)$ by using the instrument Land2001T.

The cyclic voltammogram (CV) curves were obtained between the cutoff voltage ranges of $2.0 \sim 4.8 \mathrm{~V}$ on an IM6 electrochemical workstation at a scan rate of $0.1 \mathrm{mV} / \mathrm{s}$.

\section{Results and Discussion}

3.1. TG-DTG Analysis. TG-DTG curves of the gel precursor of $\mathrm{LiNi}_{1 / 3} \mathrm{Co}_{1 / 3} \mathrm{Mn}_{1 / 3} \mathrm{O}_{2}$ and $\mathrm{LiNi}_{1 / 3} \mathrm{Co}_{1 / 3} \mathrm{Mn}_{1 / 3} \mathrm{O}_{2-0.10} \mathrm{Cl}_{0.10}$ are shown in Figure 1. There is little change in the two profiles. The first weight loss occurs at the range of $100-$ $200^{\circ} \mathrm{C}$, which corresponds to the removal of water molecules staying in the gel surface and the crystallization water of the acetates. The second weight loss is due to the decomposition of citric acid and the decomposition of anhydrous acetate to produce $\mathrm{CH}_{3} \mathrm{COCH}_{3(\mathrm{~g})}$ and metal carbonates in the temperature region of $200^{\circ} \mathrm{C}-400^{\circ} \mathrm{C}$ [15]. A slow weight loss could be observed between $400-800^{\circ} \mathrm{C}$ in the curve, which is attributed to conversion of the metal carbonates into $\mathrm{MO}_{(\mathrm{s})}, \mathrm{CO}_{2(\mathrm{~g})}$, and $\mathrm{CO}_{(\mathrm{g})}$. There is little weight loss to be observed over $800^{\circ} \mathrm{C}$, which indicates that the $\mathrm{LiNi}_{1 / 3} \mathrm{Co}_{1 / 3} \mathrm{Mn}_{1 / 3} \mathrm{O}_{2-x} \mathrm{Cl}_{x}$ phase has formed at around $800^{\circ} \mathrm{C}$.

3.2. X-Ray Diffraction Analysis. Figure 2 shows the typical $\mathrm{X}$ ray diffraction patterns of $\mathrm{LiNi}_{1 / 3} \mathrm{Co}_{1 / 3} \mathrm{Mn}_{1 / 3} \mathrm{O}_{2-x} \mathrm{Cl}_{x} \quad(x=$ $0.00,0.05,0.10,0.15$ ) cathode materials by calcining at $850^{\circ} \mathrm{C}$ for $20 \mathrm{~h}$ in air atmosphere. The XRD patterns of samples show that no impurity phase exists, which indicates that the samples have the hexagonal $\alpha-\mathrm{NaFeO}_{2}$ structure (space group, $\mathrm{R} \overline{3} \mathrm{~m})$. The clear peak splits of $(006) /(102)$ and $(108) /(110)$ doublets exhibit a high degree of ordered hexagonal layered structure. Table 1 presents the lattice parameters of $\mathrm{LiNi}_{1 / 3} \mathrm{Co}_{1 / 3} \mathrm{Mn}_{1 / 3} \mathrm{O}_{2-x} \mathrm{Cl}_{x}(x=0.00,0.05$, $0.10,0.15)$ cathode materials. The integrated intensity ratio of $(003) /(104)$ peak is more than 1.2 for all samples, and the biggest ratio 1.38 is obtained when the chlorine content is 0.10 , suggesting that a small amount of $\mathrm{Cl}^{-}$substitution for $\mathrm{O}^{2-}$ could suppress occupancy of $\mathrm{Li}^{+}$layers by $\mathrm{Ni}^{2+}$ and be conducive to the performance during electrochemical cycling [16]. The crystal structure has a little difference after chlorine doping, indicating the heteroelement has been incorporated into the $\mathrm{LiNi}_{1 / 3} \mathrm{Co}_{1 / 3} \mathrm{Mn}_{1 / 3} \mathrm{O}_{2}$ structure $[17,18]$. The increase of lattice parameter $a$ may be attributed to the valence balance by the chlorine doping leading to $\mathrm{Mn}^{4+}(0.53 \AA)$ transform to $\mathrm{Mn}^{3+}(0.58 \AA)$ or $\mathrm{Co}^{3+}(0.545 \AA)$ transform to $\mathrm{Co}^{2+}(0.65 \AA)$ in these compounds [19], while the increase of lattice parameter $c$ may be due to the difference of radius between $\mathrm{Cl}^{-}(1.81 \AA)$ and $\mathrm{O}^{2-}(1.40 \AA)$. Furthermore, the $c / a$ ratio is greater than 4.9 , which reveals a high cation ordering of the synthesized compounds [20]. 


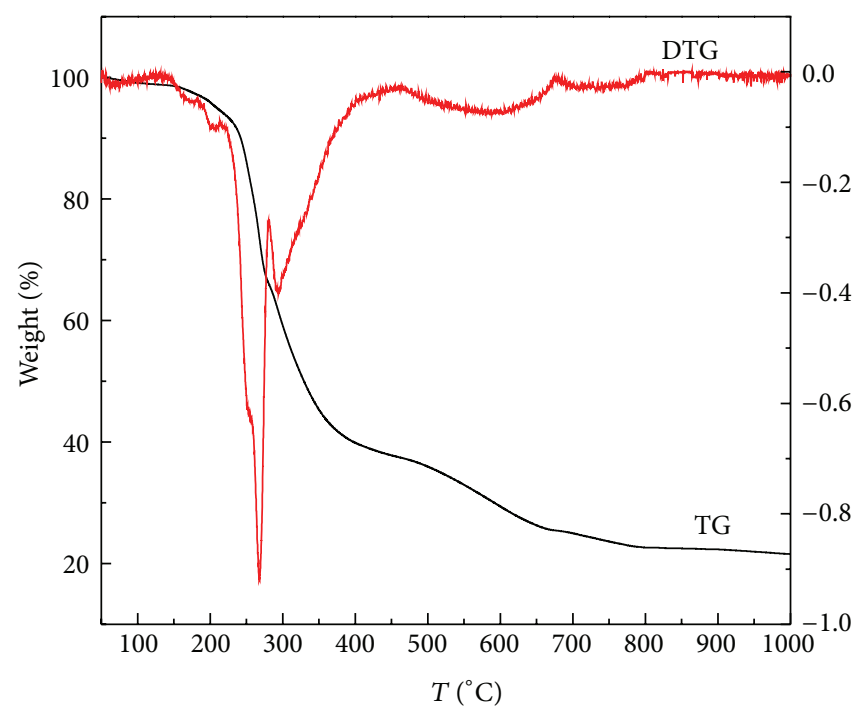

(a)

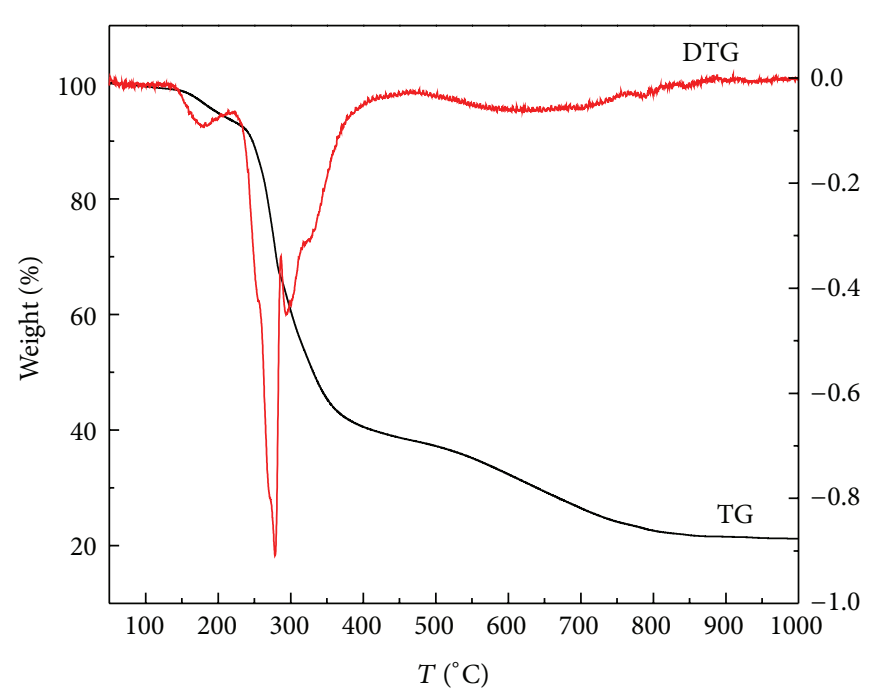

(b)

Figure 1: TG/DTG curves of the gel precursor of (a) $\mathrm{LiNi}_{1 / 3} \mathrm{Co}_{1 / 3} \mathrm{Mn}_{1 / 3} \mathrm{O}_{2}$ and (b) $\mathrm{LiNi}_{1 / 3} \mathrm{Co}_{1 / 3} \mathrm{Mn}_{1 / 3} \mathrm{O}_{2-0.10} \mathrm{Cl}_{0.10}$.

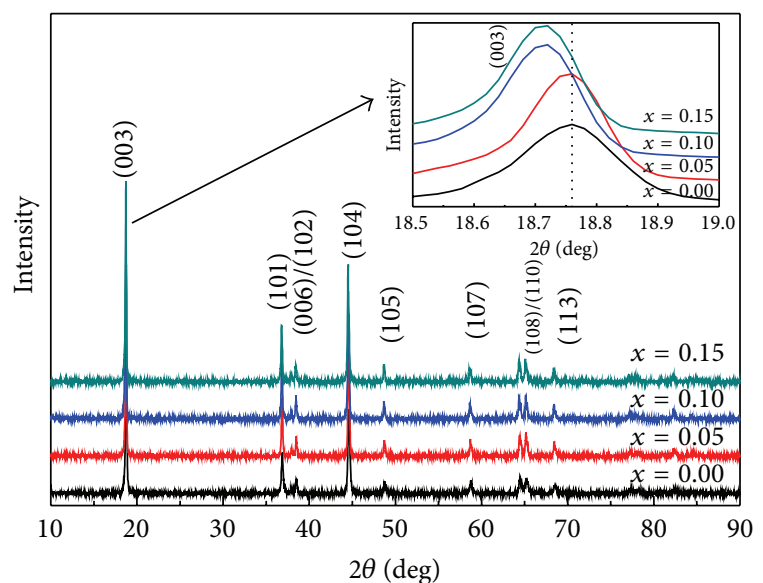

FIGURE 2: XRD patterns of $\mathrm{LiNi}_{1 / 3} \mathrm{Co}_{1 / 3} \mathrm{Mn}_{1 / 3} \mathrm{O}_{2-x} \mathrm{Cl}_{x}$ cathode materials.

3.3. Electrochemical Studies. The initial charge-discharge curves of $\mathrm{LiNi}_{1 / 3} \mathrm{Co}_{1 / 3} \mathrm{Mn}_{1 / 3} \mathrm{O}_{2-x} \mathrm{Cl}_{x}(x=0.00,0.05,0.10$, $0.15)$ over a voltage range of $2.0-4.4 \mathrm{~V}$ at $55^{\circ} \mathrm{C}$ are shown in Figure 3. As for the initial discharge capacity, the materials exhibit 170.2 $178.9,180.1$, and $179.7 \mathrm{mAh} \cdot \mathrm{g}^{-1}$, respectively, and the initial coulombic efficiencies are $90.4 \%, 93.3 \%, 93.0 \%$, and $95.7 \%$, respectively, for $x=0.00$ to 0.15 at a current rate of $0.1 \mathrm{C}$. The $95.7 \%$ initial coulombic efficiency may be the highest value for $\mathrm{LiNi}_{1 / 3} \mathrm{Co}_{1 / 3} \mathrm{Mn}_{1 / 3} \mathrm{O}_{2}$ in the world as we have known.

That the Cl-doped materials have higher discharge capacities than bare materials is attributed to the valence balance caused by chlorine addition, which may lead $\mathrm{Ni}^{3+}$ and $\mathrm{Ni}^{4+}$ to almost be completely reduced to $\mathrm{Ni}^{2+}$, decreasing the initial irreversible capacity [9]. Another reason is due

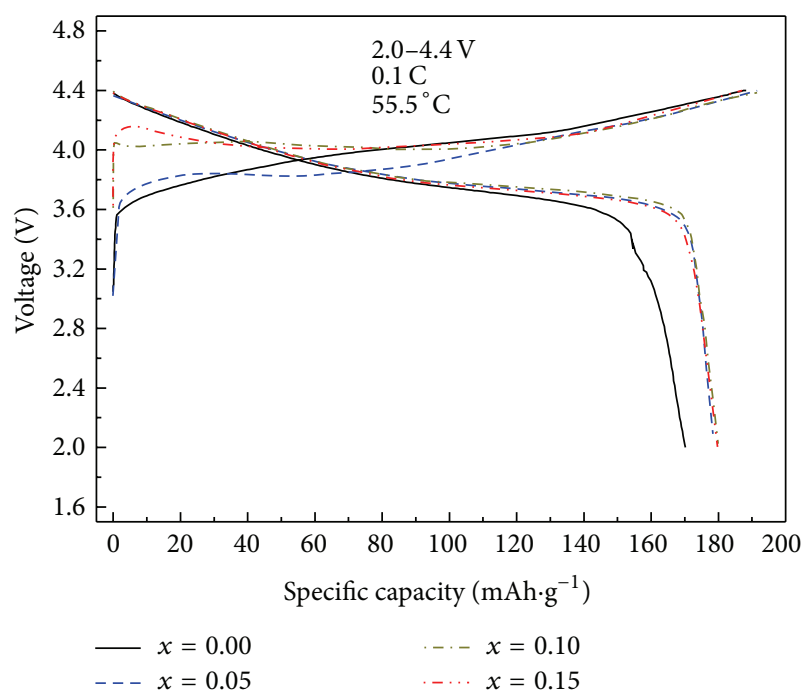

FIGURE 3: Initial charge-discharge curves of $\mathrm{LiNi}_{1 / 3} \mathrm{Co}_{1 / 3} \mathrm{Mn}_{1 / 3} \mathrm{O}_{2-x} \mathrm{Cl}_{x}$ cathode materials.

to that $\mathrm{Cl}$-doped materials have lower electronstatic repulsions between $\mathrm{O}-\mathrm{M}-\mathrm{O}$ interlayers in the process of $\mathrm{Li}^{+}$ insertion/deinsertion for $\mathrm{Cl}^{-}$has one valence electron less than $\mathrm{O}^{2-}$, which is beneficial for the removal of $\mathrm{Li}^{+}$insertion/deinsertion [13]. Furthermore, the initial irreversible capacity loss of the materials also may be involved with the formation of surface electrolyte interphase (SEI) film [21].

The cyclic performance and rate capability of $\mathrm{LiNi}_{1 / 3} \mathrm{Co}_{1 / 3} \mathrm{Mn}_{1 / 3} \mathrm{O}_{2-x} \mathrm{Cl}_{x}(x=0.00,0.05,0.10,0.15)$ cathode materials are illustrated in Figure 4 . All cells were operated by the steps of 2 cycles at $0.1 \mathrm{C}, 3$ cycles at $0.15 \mathrm{C}, 5$ cycles at $0.25 \mathrm{C}, 87$ cycles at $0.5 \mathrm{C}$, and the final 3 cycles at $0.1 \mathrm{C}$ between $2.0 \mathrm{~V}$ and $4.4 \mathrm{~V}$. At the 97 th cycle the discharge 


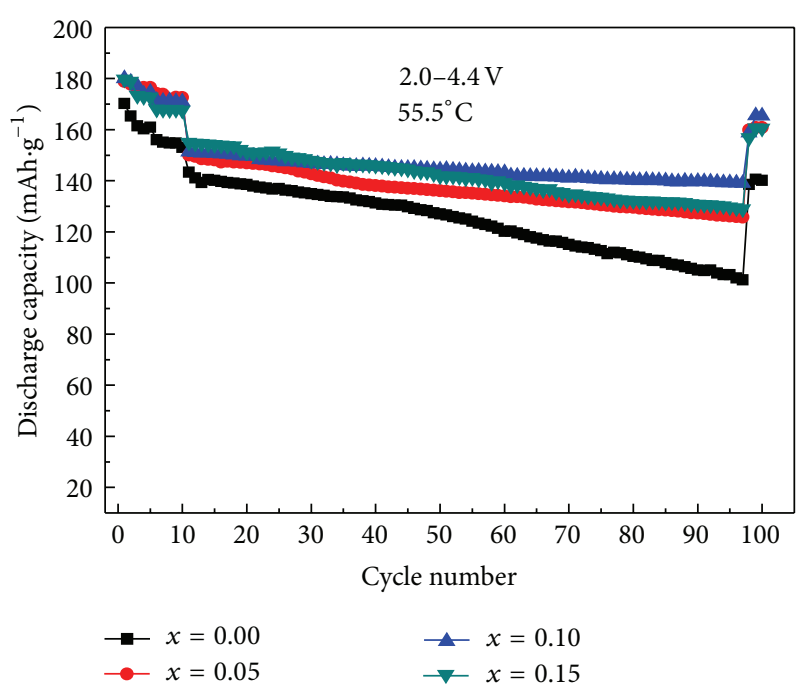

Figure 4: Cyclic performance of $\mathrm{LiNi}_{1 / 3} \mathrm{Co}_{1 / 3} \mathrm{Mn}_{1 / 3} \mathrm{O}_{2-x} \mathrm{Cl}_{x}$ cathode materials at different rates.

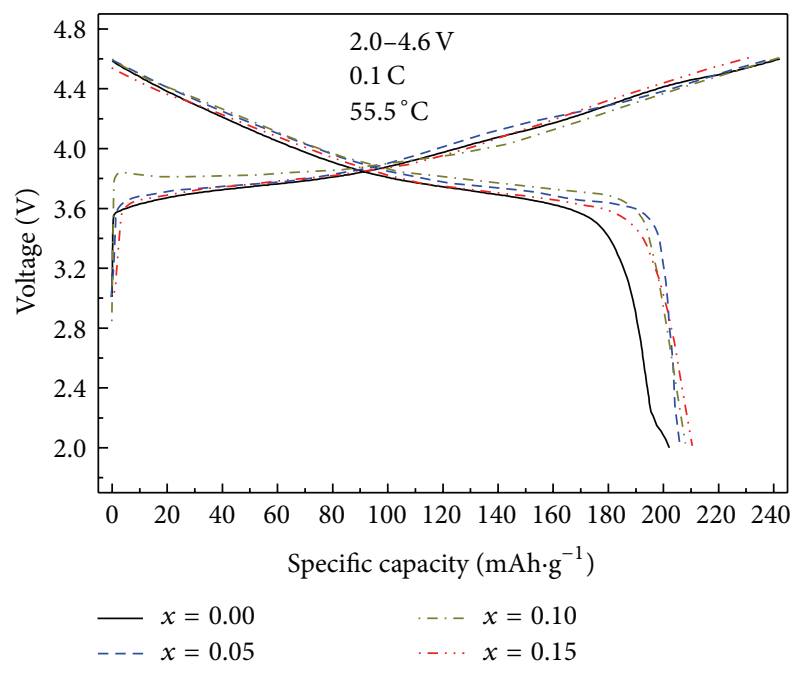

FIGURE 5: Initial charge-discharge curves of $\mathrm{LiNi}_{1 / 3} \mathrm{Co}_{1 / 3} \mathrm{Mn}_{1 / 3} \mathrm{O}_{2-x} \mathrm{Cl}_{x}$ cathode materials.

capacities at $0.5 \mathrm{C}$ are $101.2,125.7,139.1$, and $129 \mathrm{mAh} \cdot \mathrm{g}^{-1}$, which are $70.6 \%, 83.7 \%, 91.9 \%$, and $85.5 \%$ of the 11 th cycle at $0.5 \mathrm{C}$ for $x=0.00$ to 0.15 , respectively. And after 100 cycles the capacities at $0.1 \mathrm{C}$ are $82.4 \%, 89.9 \%, 91.8 \%$, and $89.3 \%$ of the initial discharge capacity at $0.1 \mathrm{C}$, respectively.

It is worth noting that Cl-doped materials exhibit high discharge specific capacity, excellent cyclic stability, and good rate performance. The ion radius of $\mathrm{Cl}^{-}$is larger than $\mathrm{O}^{2-}$, expanding pathway for $\mathrm{Li}^{+}$to intercalate and deintercalate. Moreover, Li et al. [13] reported that $\mathrm{Li}^{+}$can be more freely deintercalated due to that $\mathrm{Cl}^{-}$is easier to lose electron than $\mathrm{O}^{2-}$. However, the structural stability slightly decreases with the increase of chlorine content; one reason may be for larger lattice parameters $c$ and $V$ and the other may be due to valence balance. So the capacity retention for $x=0.15$ is lower than that with the chlorine content of 0.10 .

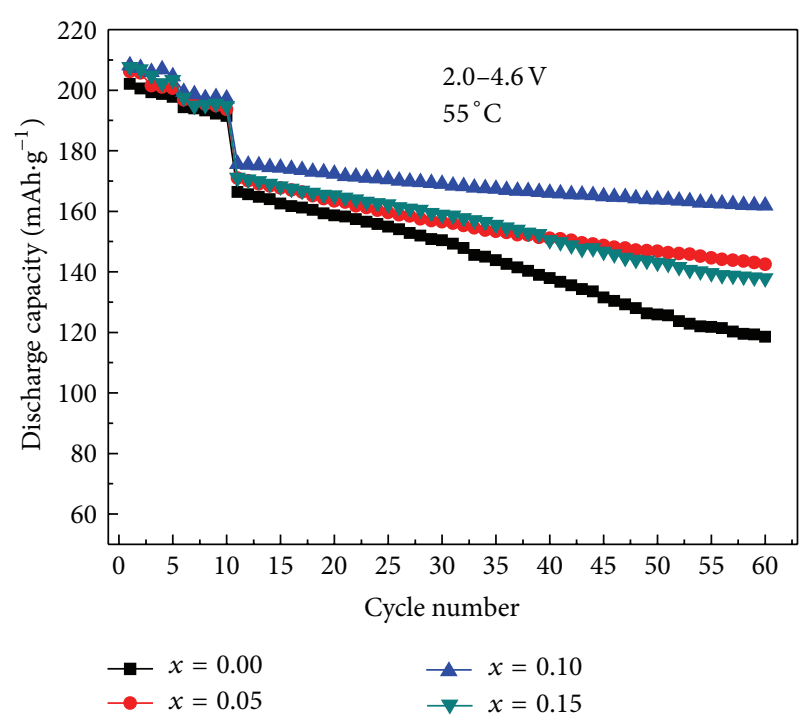

Figure 6: Cyclic performance of $\mathrm{LiNi}_{1 / 3} \mathrm{Co}_{1 / 3} \mathrm{Mn}_{1 / 3} \mathrm{O}_{2-x} \mathrm{Cl}_{x}$ cathode materials at different rates.

Figure 5 shows the initial charge-discharge curves when the charge cutoff potential is up to $4.6 \mathrm{~V}$ at $0.1 \mathrm{C}$. The initial discharge capacities are 202.1, 206.2, 208.2, and $207.7 \mathrm{mAh} \cdot \mathrm{g}^{-1}$, respectively, and the initial coulombic efficiencies are $83.4 \%, 86.0 \%, 85.6 \%$ and $91.1 \%$ for $x=$ 0.00 to 0.15 , respectively. The initial coulombic efficiency decreases with the increase of charge cutoff potential. Figure 6 shows the cyclic performances and rate capabilities of $\mathrm{LiNi}_{1 / 3} \mathrm{Co}_{1 / 3} \mathrm{Mn}_{1 / 3} \mathrm{O}_{2-x} \mathrm{Cl}_{x}(x=0.00,0.05,0.10,0.15)$ cathode materials between $2.0 \mathrm{~V}$ and $4.6 \mathrm{~V}$. All cells were operated by the steps of 2 cycles at $0.1 \mathrm{C}, 3$ cycles at $0.15 \mathrm{C}, 5$ cycles at $0.25 \mathrm{C}$, and the final 50 cycles at $0.5 \mathrm{C}$. The discharge capacities of the 11th cycle at $0.5 \mathrm{C}$ are 166.4, 170.9, 175.6, and $171.1 \mathrm{mAh} \cdot \mathrm{g}^{-1}$, respectively; and at the 60 th cycle the discharge capacities are $71.2 \%, 83.4 \%, 92.2 \%$ and $80.6 \%$ of the 11 th cycle at $0.5 \mathrm{C}$ for $x=0.00$ to 0.15 , respectively. It is worthy to note that the discharge capacity increases but leads to fast capacity fading with the increasing of cutoff voltage, especially for the bare material. Kim et al. [19] have reported that the capacity fading is mainly due to the Co dissolution during cycling in high voltage cutoff. However, the $\mathrm{Cl}^{-}$doping leads to improvement in capacity retention at the high-voltage region, which indicates that chlorine addition has enhanced the electrochemical performance.

3.4. Cyclic Voltammetry $(\mathrm{CV})$. Figure 7 presents the first cyclic voltammogram curves of $\mathrm{LiNi}_{1 / 3} \mathrm{Co}_{1 / 3} \mathrm{Mn}_{1 / 3} \mathrm{O}_{2}$ and $\mathrm{LiNi}_{1 / 3} \mathrm{Co}_{1 / 3} \mathrm{Mn}_{1 / 3} \mathrm{O}_{2-x} \mathrm{Cl}_{x}$ cathode materials in the voltage range of $2.0-4.8 \mathrm{~V}$ at a scan rate of $0.1 \mathrm{mV} / \mathrm{s}$. Evidently two redox peaks at 4.078/3.632 $\mathrm{V}$ and $4.608 / 4.497 \mathrm{~V}$ are found in the curve of bare sample, indicating that two phase transitions occurred in the charge-discharge process. Shaju et al. [4] have reported that the large redox peak and the small redox peak are corresponding to $\mathrm{Ni}^{2+/ 4+}$ and $\mathrm{Co}^{3+/ 4+}$, respectively. It is reported that the capacity fade of the layer-structured 


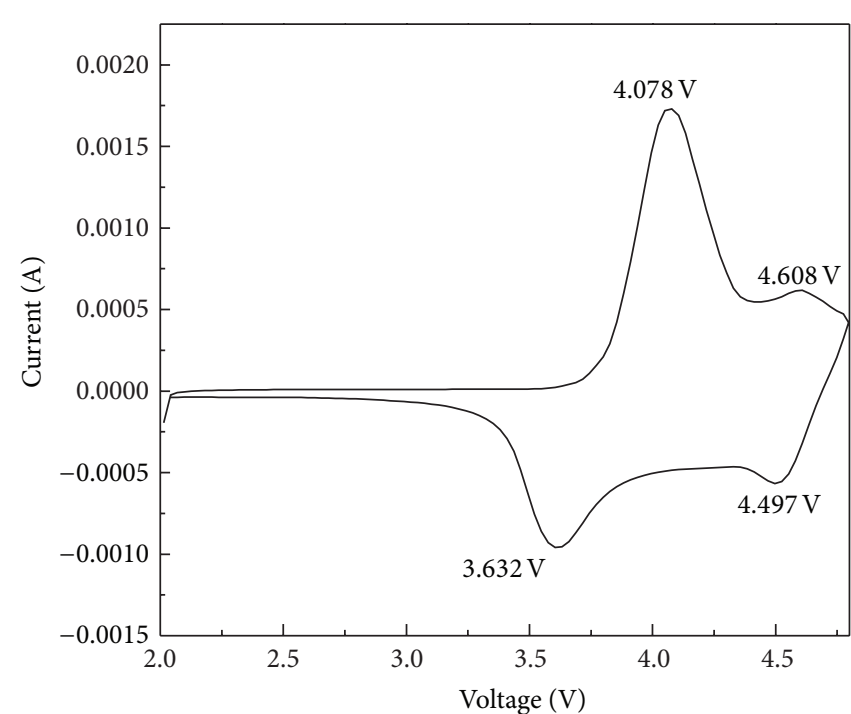

(a)

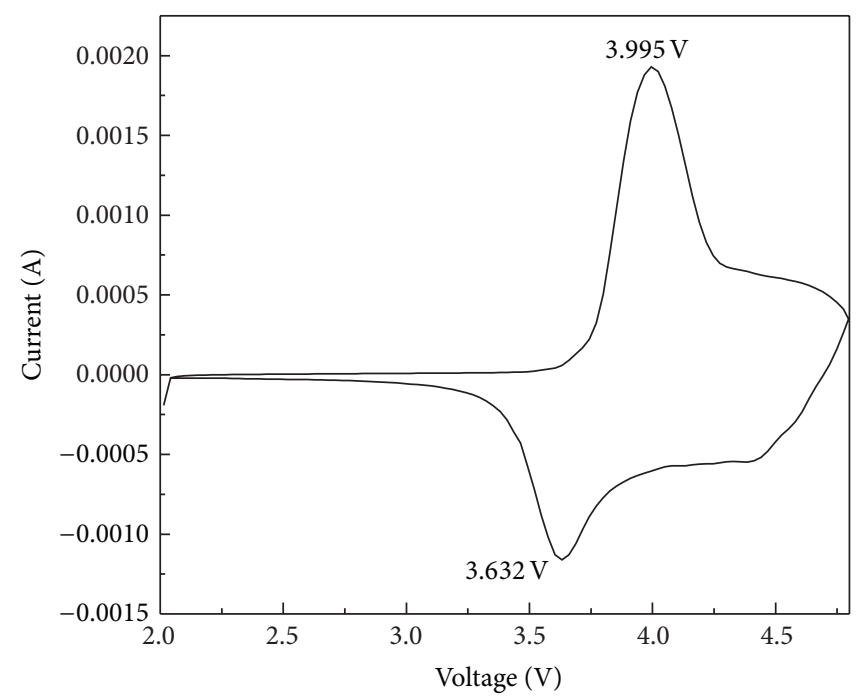

(c)

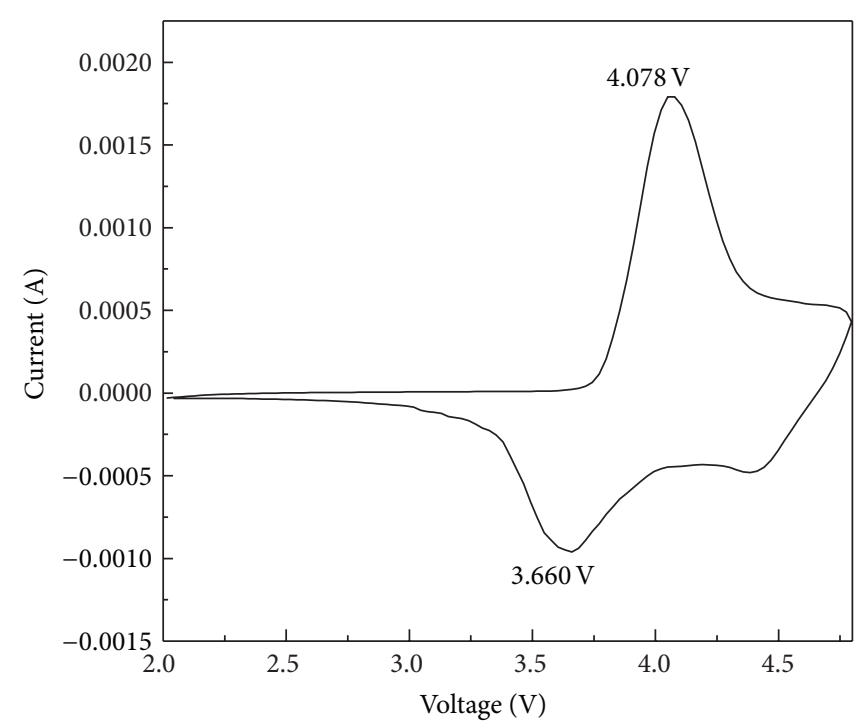

(b)

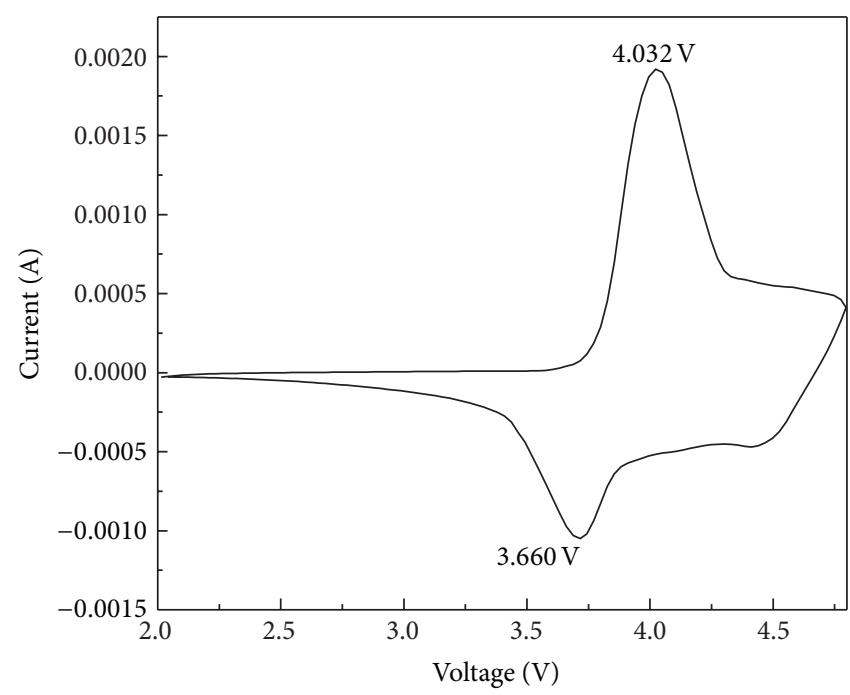

(d)

Figure 7: Cyclic voltammograms for the first curves obtained from $\mathrm{LiNi}_{1 / 3} \mathrm{Co}_{1 / 3} \mathrm{Mn}_{1 / 3} \mathrm{O}_{2-x} \mathrm{Cl}_{x}$ for (a) $x=0.00$; (b) $x=0.05$; (c) $x=0.10$; (d) $x=0.15$.

cathode materials is associated with structural transitions from hexagonal to monoclinic to hexagonal modifications at potentials above $4.1 \mathrm{~V}[22,23]$. There is only one redox peak in the curves of Cl-doped materials, which means that $\mathrm{Cl}^{-}$, as a doping material, suppresses the structure transitions from hexagonal to monoclinic structure.

\section{Conclusions}

The $\mathrm{LiNi}_{1 / 3} \mathrm{Co}_{1 / 3} \mathrm{Mn}_{1 / 3} \mathrm{O}_{2-x} \mathrm{Cl}_{x}(x=0.00,0.05,0.10,0.15)$ cathode materials have been successfully synthetized by a sol-gel method. Partial $\mathrm{O}^{2-}$ substitution by $\mathrm{Cl}^{-}$increases the lattice parameters $c$, and $V . \mathrm{LiNi}_{1 / 3} \mathrm{Co}_{1 / 3} \mathrm{Mn}_{1 / 3} \mathrm{O}_{1.90} \mathrm{Cl}_{10}$ cathode material shows higher initial discharge capacity of $180.1 \mathrm{mAh} \cdot \mathrm{g}^{-1}$ at $0.1 \mathrm{C}$ in a voltage range of $2.0-4.4 \mathrm{~V}$, and the capacity retention was $91.9 \%$ after 100 cycles at $55^{\circ} \mathrm{C}$, while for the undoped material they are $170.2 \mathrm{mAh} \cdot \mathrm{g}^{-1}$ and $82.4 \%$, respectively. It should be confirmed that a small amount of $\mathrm{Cl}$ doping could improve the cyclic property of $\mathrm{LiNi}_{1 / 3} \mathrm{Co}_{1 / 3} \mathrm{Mn}_{1 / 3} \mathrm{O}_{2}$ a great deal and also increase the discharge capacity. Although the initial discharge capacity increases when the charge cutoff voltage is up to $4.6 \mathrm{~V}$, the capacity retention and rate capability for the bare material decrease. Chlorine addition has improved the electrochemical performance in the higher charge cutoff voltage. CV shows that only one redox peak is observed for Cl-doped materials, which means that there is no structural transition from hexagonal to monoclinic in this area. Chlorine doping has been demonstrated to be a good way for improving the property of $\mathrm{LiNi}_{1 / 3} \mathrm{Co}_{1 / 3} \mathrm{Mn}_{1 / 3} \mathrm{O}_{2}$. $\mathrm{LiNi}_{1 / 3} \mathrm{Co}_{1 / 3} \mathrm{Mn}_{1 / 3} \mathrm{O}_{1.90} \mathrm{Cl}_{10}$ 
would be a promising candidate cathode material for next generation Li-ion battery.

\section{References}

[1] C. Delmas, J. P. Pérès, A. Rougier et al., "On the behavior of the $\mathrm{LixNiO}_{2}$ system: an electrochemical and structural overview," Journal of Power Sources, vol. 68, no. 1, pp. 120-125, 1997.

[2] G. G. Amatucci, C. N. Schmutz, A. Blyr et al., "Materials' effects on the elevated and room temperature performance of C/LiMn ${ }_{2} \mathrm{O}_{4}$ Li-ion batteries," Journal of Power Sources, vol. 69, no. 1-2, pp. 11-25, 1997.

[3] A. S. Andersson and J. O. Thomas, "The source of first-cycle capacity loss in $\mathrm{LiFePO}_{4}$," Journal of Power Sources, vol. 97-98, pp. 498-502, 2001.

[4] K. M. Shaju, G. V. Subba Rao, and B. V. R. Chowdari, "Performance of layered $\mathrm{Li}\left(\mathrm{Ni}_{1 / 3} \mathrm{Co}_{1 / 3} \mathrm{Mn}_{1 / 3}\right) \mathrm{O}_{2}$ as cathode for Li-ion batteries," Electrochimica Acta, vol. 48, no. 2, pp. 145-151, 2002.

[5] Y.-J. Shin, W.-J. Choi, Y.-S. Hong, S. Yoon, K. S. Ryu, and S. H. Chang, "Investigation on the microscopic features of layered oxide $\mathrm{Li}\left[\mathrm{Ni}_{1 / 3} \mathrm{Co}_{1 / 3} \mathrm{Mn}_{1 / 3}\right] \mathrm{O}_{2}$ and their influences on the cathode properties," Solid State Ionics, vol. 177, no. 5-6, pp. 515-521, 2006.

[6] Y. Koyama, N. Yabuuchi, I. Tanaka, H. Adachi, and T. Ohzuku, "Solid-state chemistry and electrochemistry of $\mathrm{LiCo}_{1 / 3} \mathrm{Ni}_{1 / 3} \mathrm{Mn}_{1 / 3} \mathrm{O}_{2}$ for advanced lithium-ion batteries I. First-principles calculation on the crystal and electronic structures," Journal of the Electrochemical Society, vol. 151, no. 10, pp. A1545-A1551, 2004.

[7] H. Liu and L. Tan, "High rate performance of novel cathode material $\mathrm{Li}_{1.33} \mathrm{Ni}_{1 / 3} \mathrm{Co}_{1 / 3} \mathrm{Mn}_{1 / 3} \mathrm{O}_{2}$ for lithium ion batteries," Materials Chemistry and Physics, vol. 129, pp. 729-732, 2011.

[8] S. H. Park, C. S. Yoon, S. G. Kang, H.-S. Kim, S.-I. Moon, and Y.-K. Sun, "Synthesis and structural characterization of layered $\mathrm{Li}\left[\mathrm{Ni}_{1 / 3} \mathrm{Co}_{1 / 3} \mathrm{Mn}_{1 / 3}\right] \mathrm{O}_{2}$ cathode materials by ultrasonic spray pyrolysis method," Electrochimica Acta, vol. 49, no. 4, pp. 557563, 2004.

[9] Y. W. Tsai, B. J. Hwang, G. Ceder, H. S. Sheu, D. G. Liu, and J. F. Lee, "In-situ X-ray absorption spectroscopic study on variation of electronic transitions and local structure of $\mathrm{LiNi}_{1 / 3} \mathrm{Co}_{1 / 3} \mathrm{Mn}_{1 / 3} \mathrm{O}_{2}$ cathode material during electrochemical cycling," Chemistry of Materials, vol. 17, no. 12, pp. 3191-3199, 2005.

[10] D. C. Li, Y. Sasaki, K. Kobayakawa, H. Noguchi, and Y. Sato, "Preparation, morphology and electrochemical characteristics of $\mathrm{LiNi}_{1 / 3} \mathrm{Mn}_{1 / 3} \mathrm{Co}_{1 / 3} \mathrm{O}_{2}$ with LiF addition," Electrochimica Acta, vol. 52, no. 2, pp. 643-648, 2006.

[11] Y. S. He, L. Pei, X. Z. Liao, and Z. F. Ma, "Synthesis of $\mathrm{LiNi}_{1 / 3} \mathrm{Co}_{1 / 3} \mathrm{Mn}_{1 / 3} \mathrm{O}_{2-z} \mathrm{~F}_{z}$ cathode material from oxalate precursors for lithium ion battery," Journal of Fluorine Chemistry, vol. 128, pp. 139-143, 2007.

[12] K.-H. Dai, Y.-T. Xie, Y.-J. Wang, Z.-S. Song, and Q. Qilu, "Effect of fluorine in the preparation of $\mathrm{Li}\left(\mathrm{Ni}_{1 / 3} \mathrm{Co}_{1 / 3} \mathrm{Mn}_{1 / 3}\right) \mathrm{O}_{2}$ via hydroxide co-precipitation," Electrochimica Acta, vol. 53, no. 8, pp. 3257-3261, 2008.

[13] X. L. Li, F. Y. Kang, W. C. Shen, and X. D. Bai, "Improvement of structural stability and electrochemical activity of a cathode material $\mathrm{LiNi}_{0.7} \mathrm{Co}_{0.3} \mathrm{O}_{2}$ by chlorine doping," Electrochimica Acta, vol. 53, no. 4, pp. 1761-1765, 2007.

[14] C. S. Sun, Y. Zhang, X. J. Zhang, and Z. Zhou, "Structural and electrochemical properties of Cl-doped $\mathrm{LiFePO}_{4} / \mathrm{C}$," Journal of Power Sources, vol. 195, no. 11, pp. 3680-3683, 2010.
[15] C. Nithya, V. S. Syamala Kumari, and S. Gopukumar, "Synthesis of high voltage $(4.9 \mathrm{~V})$ cycling $\mathrm{LiNi}_{x} \mathrm{Co}_{y} \mathrm{Mn}_{1-x-y} \mathrm{O}_{2}$ cathode materials for lithium rechargeable batteries," Physical Chemistry Chemical Physics, vol. 13, no. 13, pp. 6125-6132, 2011.

[16] R. Santhanam, P. Jones, A. Sumana, and B. Rambabu, "Influence of lithium content on high rate cycleability of layered $\mathrm{Li}_{1+x} \mathrm{Ni}_{0.30} \mathrm{Co}_{0.30} \mathrm{Mn}_{0.40} \mathrm{O}_{2}$ cathodes for high power lithium-ion batteries," Journal of Power Sources, vol. 195, no. 21, pp. 73917396, 2010.

[17] S.-T. Myung, K. Izumi, S. Komaba, Y.-K. Sun, H. Yashiro, and N. Kumagai, "Role of alumina coating on Li-Ni-Co$\mathrm{Mn}-\mathrm{O}$ particles as positive electrode material for lithium-ion batteries," Chemistry of Materials, vol. 17, no. 14, pp. 3695-3704, 2005.

[18] S.-T. Myung, K. Izumi, S. Komaba et al., "Functionality of oxide coating for $\mathrm{Li}\left[\mathrm{Li}_{0.05} \mathrm{Ni}_{0.4} \mathrm{Co}_{0.15} \mathrm{Mn}_{0.4}\right] \mathrm{O}_{2}$ as positive electrode materials for lithium-ion secondary batteries," Journal of Physical Chemistry C, vol. 111, no. 10, pp. 4061-4067, 2007.

[19] G.-H. Kim, J.-H. Kim, S.-T. Myung, C. S. Yoon, and Y.K. Sun, "Improvement of high-voltage cycling behavior of surface-modified $\mathrm{Li}\left[\mathrm{Ni}_{1 / 3} \mathrm{Co}_{1 / 3} \mathrm{Mn}_{1 / 3}\right] \mathrm{O}_{2}$ cathodes by fluorine substitution for Li-ion batteries," Journal of the Electrochemical Society, vol. 152, no. 9, pp. A1707-A1713, 2005.

[20] J.-W. Lee, J.-H. Lee, T. T. Viet, J.-Y. Lee, J.-S. Kim, and C.-H. Lee, "Synthesis of $\mathrm{LiNi}_{1 / 3} \mathrm{Co}_{1 / 3} \mathrm{Mn}_{1 / 3} \mathrm{O}_{2}$ cathode materials by using a supercritical water method in a batch reactor," Electrochimica Acta, vol. 55, no. 8, pp. 3015-3021, 2010.

[21] Z.-D. Huang, X.-M. Liu, S.-W. Oh, B. Zhang, P.-C. Ma, and J.K. Kim, "Microscopically porous, interconnected single crystal $\mathrm{LiNi}_{1 / 3} \mathrm{Co}_{1 / 3} \mathrm{Mn}_{1 / 3} \mathrm{O}_{2}$ cathode material for Lithium ion batteries," Journal of Materials Chemistry, vol. 21, no. 29, pp. 1077710784, 2011.

[22] G. T.-K. Fey, Y. Y. Lin, and T. Prem Kumar, "Enhanced cyclability and thermal stability of $\mathrm{LiCoO}_{2}$ coated with cobalt oxides," Surface and Coatings Technology, vol. 191, no. 1, pp. 6875, 2005.

[23] H. Cao, Y. Zhang, J. Zhang, and B. Xia, "Synthesis and electrochemical characteristics of layered $\mathrm{LiNi}_{0.6} \mathrm{Co}_{0.2} \mathrm{Mn}_{0.2} \mathrm{O}_{2}$ cathode material for lithium ion batteries," Solid State Ionics, vol. 176, no. 13-14, pp. 1207-1211, 2005. 

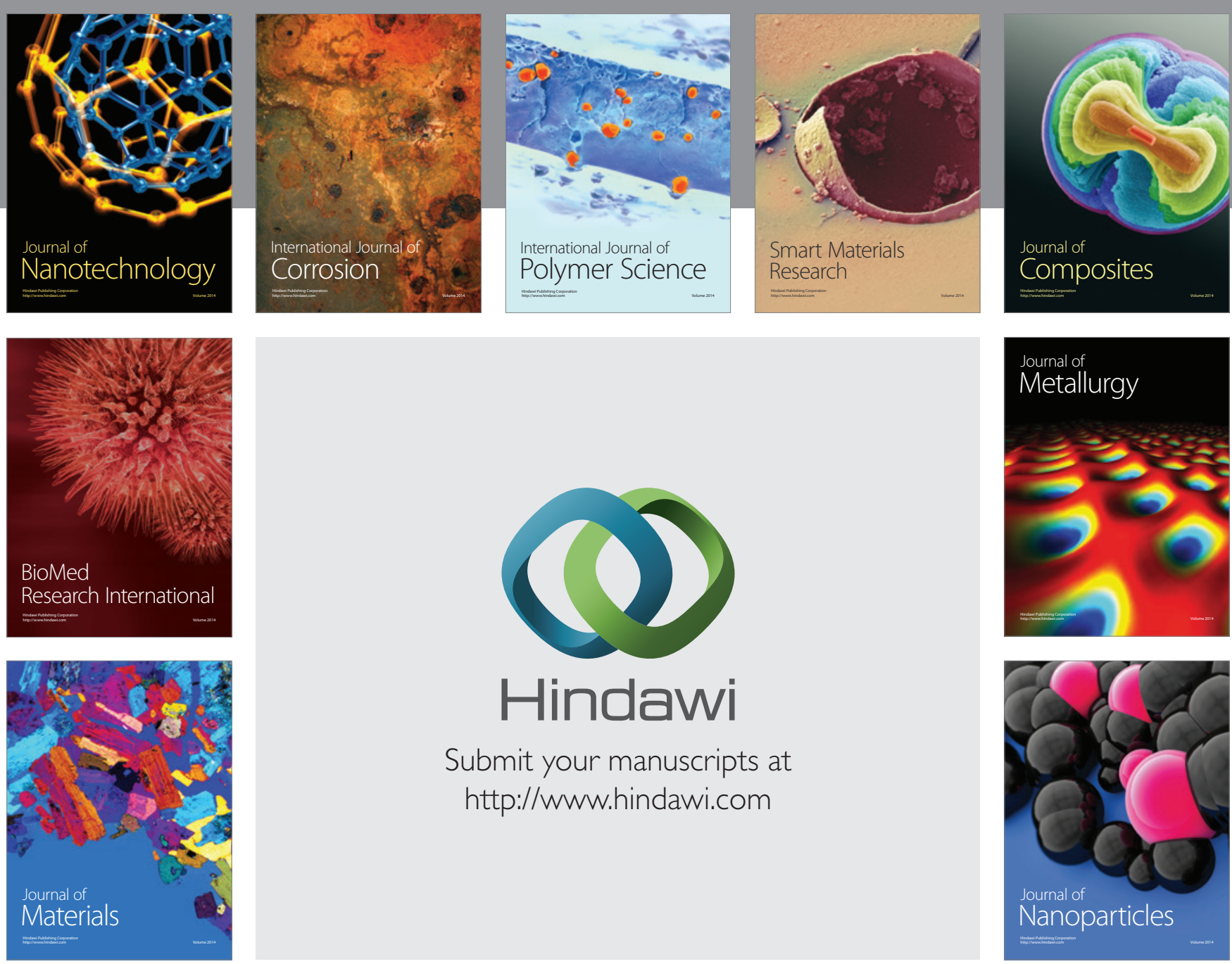

Submit your manuscripts at http://www.hindawi.com
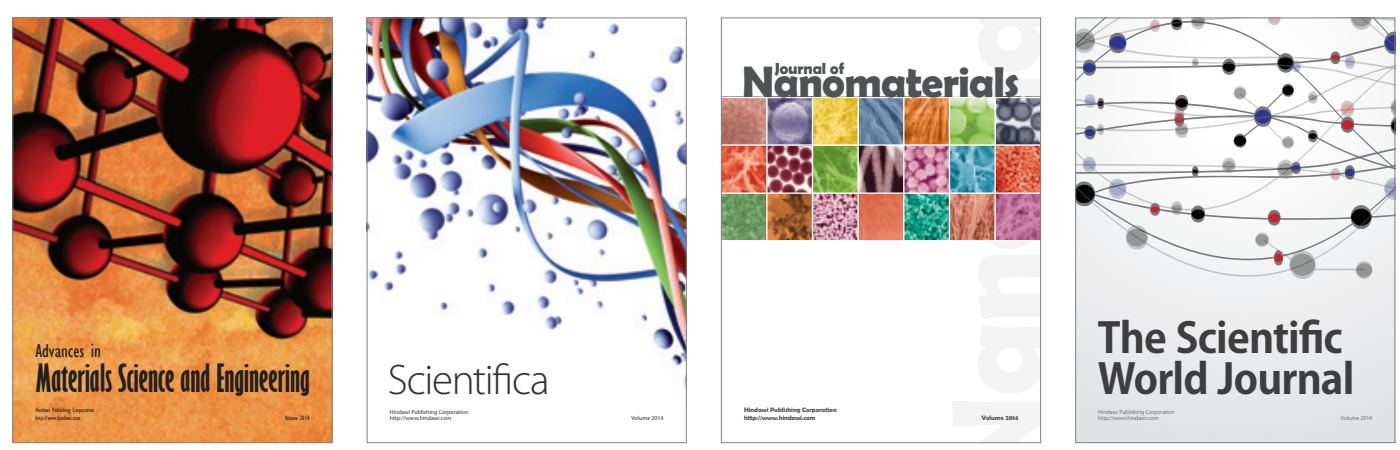

\section{The Scientific World Journal}
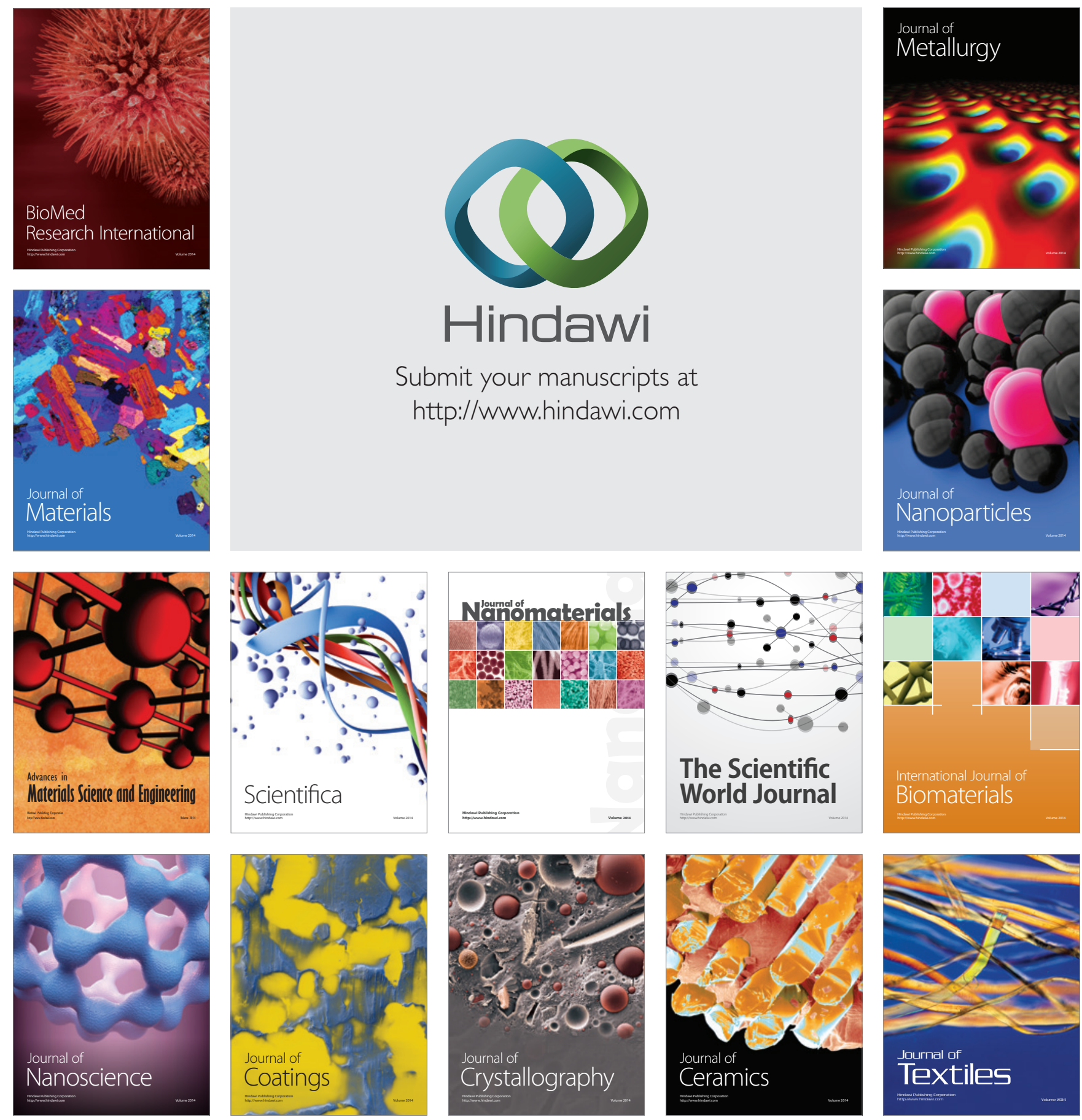